\title{
ATP P2X3 receptors and neuronal sensitization
}

\author{
Elsa Fabbretti* \\ University of Nova Gorica, Center for Biomedical Sciences and Engineering, Nova Gorica, Slovenia
}

\section{Edited by:}

Geoffrey Burnstock, University College

Medical School London, UK

Reviewed by:

Felicita Pedata, University of Florence, Italy

Miranda Mladinic, University of Rijeka, Croatia

*Correspondence:

Elsa Fabbretti, University of Nova Gorica, Center for Biomedical

Sciences and Engineering, Vipavska

13, Sl-5000 Gorica, Nova Gorica,

Slovenia

e-mail: elsa.fabbretti@ung.si
Increasing evidence indicates the importance of extracellular adenosine triphosphate (ATP) in the modulation of neuronal function. In particular, fine control of ATP release and the selective and discrete ATP receptor operation are crucial elements of the crosstalk between neuronal and non-neuronal cells in the peripheral and central nervous systems. In peripheral neurons, ATP signaling gives an important contribution to neuronal sensitization, especially that involved in neuropathic pain. Among other subtypes, P2X3 receptors expressed on sensory neurons are sensitive even to nanomolar concentrations of extracellular ATP, and therefore are important transducers of pain stimuli. P2X3 receptor function is highly sensitive to soluble factors like neuropeptides and neurotrophins, and is controlled by transduction mechanisms, protein-protein interactions and discrete membrane compartmentalization. More recent findings have demonstrated that P2X3 receptors interact with the synaptic scaffold protein calcium/calmodulin-dependent serine protein kinase (CASK) in a state dependent fashion, indicating that CASK plays a crucial role in the modulation of $\mathrm{P} 2 \mathrm{X} 3$ receptor stability and efficiency. Activation of P2X3 receptors within CASK/P2X3 complex has important consequences for neuronal plasticity and possibly for the release of neuromodulators and neurotransmitters. Better understanding of the interactome machinery of P2X 3 receptors and their integration with other receptors and channels on neuronal surface membranes, is proposed to be essential to unveil the process of neuronal sensitization and related, abnormal pain signaling.

Keywords: trigeminal neurons, pain, receptor plasticity, purinergic signaling, migraine

\section{INTRODUCTION \\ ADENOSINE TRIPHOSPHATE AS A CHEMICAL INDUCER OF SENSITIZATION}

Sensitization is a process whereby primary sensory neuron afferents and central synapses become hyper-responsive to extracellular nociceptive stimuli so that they underlie neuropathic and chronic pain, including allodynia, hyperalgesia and spontaneous pain. Peripheral and central sensitization are thought to be supported by enhanced release of neurotransmitters and peptides, often co-released with adenosine triphosphate (ATP), from primary afferents to spinal synapses (Bardoni et al., 1997). Activation of the corresponding receptors in postsynaptic dorsal horn neurons induces central sensitization.

Fast conductive myelinated A $\delta$ fibers and slow non-myelinated C-fibers sense different stimuli, in particular mechanical/chemical or tactile stimuli (Basbaum et al., 2009). Whether A- or Cfibers are more important for the generation of spontaneous firing in neuropathic pain, remains an unanswered question. One important priority for translational medicine is the identification of biomarkers for the functional role of distinct classes of Cfibers and $\mathrm{A} \delta$ fibers and for their transition from mono- to poly-modal function in chronic pain. It is not excluded that cellular crosstalk at ganglion level might also induce functional plasticity in non-nociceptive neurons to be recruited in persistent allodynia (Ueda, 2008). The recruitment of non-nociceptive sensory fibers generates an additional level of complexity that renders the sensitization incompletely understood in its complex molecular constituents and temporal evolution, with consequent slow development of new drugs to prevent/revert it.

One important consideration regards the differential contribution of sensory fibers in humans and rodents and, therefore, the difficulties to apply experimental data to clinically-useful models. Experiments performed with infrared diode laser stimulation on human subjects affected by painful neuropathies have demonstrated that pain conditions are associated with impaired function of $\mathrm{A} \delta$ fibers and low involvement of un-myelinated C-fibers (Tzabazis et al., 2011; Moeller-Bertram et al., 2013), while the opposite is found in rodents (Shields et al., 2010; Zhang et al., 2013). Nonetheless, a species-dependent difference in neural substrates of pain, as recently found in P2X3 receptor sequence (Serrano et al., 2012; Sundukova et al., 2012), does not exclude similar chemo-transduction mechanisms based on analogous mediators and modulators.

The molecular basis of transitions from acute sensitization to long-term hypersensitivity relies on complex temporal and spatial molecular mechanisms that are primed by exposure to soluble factors and intracellular neuronal and non-neuronal signaling. Gene expression and protein trafficking then strongly contribute to change pain receptor expression, supporting dysfunctional action potential firing into aberrant neurotransmitter release at the presynaptic terminal and, thus, inducing central sensitization of spinal and brainstem networks.

Among the soluble and cellular factors responsible for the early molecular signature of fiber sensitization and spontaneous 
aberrant firing in a variety of pain-related diseases, one powerful candidate molecule is extracellular ATP (Hamilton and McMahon, 2000), co-released with other neurotransmitters and peptides or after mechanical stress by a number of different mechanisms (Corriden and Insel, 2010; Novak, 2011). Indeed, ATP acute injection activates $\mathrm{C}$-nociceptors in healthy human skin without the involvement of mechano-responsive or mechanoinsensitive C-fibers (Hilliges et al., 2002). ATP (whose extracellular concentration is limited in time and space by ectonucleotidases that generate active metabolites) binds to different subtypes of ligand-gated P2X channels or metabotropic P2Y receptors (Burnstock, 2008), amplifying the spectrum of reactive molecules in the extracellular space (Browne and North, 2013).

Combinatorial expression of ATP receptors with different affinity for ATP in distinct cell types allows modulation of purinergic signaling in different tissues. Primary sensory neurons widely express P2X3 receptors (Vulchanova et al., 1998) sensitive to nanomolar ATP concentrations (Sokolova et al., 2006) and implicated in the modulation of pain sensitivity as demonstrated using P2X3 knockout (KO) mice (Cockayne et al., 2000; Souslova et al., 2000; Zhong et al., 2001; Cockayne et al., 2005). Recent pharmacological research has been directed to discover new drugs capable of inhibiting $\mathrm{P} 2 \mathrm{X} 3$ receptors because their pharmacological block could provide a significant contribution to reduce inflammatory and neuropathic pain (Ford, 2012; North and Jarvis, 2013). Nevertheless, only a few P2X3-selective antagonists have been reported to date (Jarvis et al., 2002; Ford, 2012) and are currently undergoing clinical trials (Fabbretti and Nistri, 2012).

While it is well known that changes in the activity of voltagegated ion channels expressed by sensory neurons can contribute to chronic pain sensitization (McCleskey and Gold, 1999), the focus of the present review is on ATP-mediated signaling since it represents an early chemical signal that triggers pain in normal circumstances and that can predate the establishment of neuronal sensitization (Hamilton and McMahon, 2000). ATP, working through different (yet unknown) plasticity processes, eventually confers novel maladaptive activity to neurons and non-neuronal cells in the entire tissue. Together with ATP, several soluble factors and neuropeptides like nerve growth factor (NGF), calcitonin gene-related peptide (CGRP), cytokines and prostaglandins cooperate either to directly activate nociceptors (as well as to induce secondary long-lasting chain of genomic changes) or to evoke indirect paracrine responses after non-neuronal cells activation (Shu and Mendell, 2001; Giniatullin et al., 2008; Jakobsson, 2010; Kuner, 2010; Cady et al., 2011).

\section{ROLE OF ATP-GATED P2X3 RECEPTORS IN NEUROGENIC INFLAMMATION AND NEURONAL SENSITIZATION}

Inflammatory mediators influence neuronal expression of nociceptors and ion channels including ATP receptors, therefore contributing to spontaneous activity of sensory fibers and closing a vicious circle of pathological hyper-responsiveness (Ellis and Bennett, 2013).

Neuronal/non-neuronal cell crosstalk is highly modulated by neuronal ATP and its action not only on P2X3 receptors but also on low affinity ATP receptors (P2X4 or P2X7) known to give a strong contribution in inflammatory response (Toulme et al., 2010; Inoue and Tsuda, 2012). In addition, the reactivity of resident microglia-like cells (macrophages) in ganglia (Villa et al., 2010; Franceschini et al., 2013a) opens new vistas on the cellular mechanisms of regulation of neuronal sensitization at ganglion level.

The inflammatory components of neuropathic pain include activation of toll-like receptors (TLR) on neurons and nonneuronal cells (Christianson et al., 2011; Stokes et al., 2013). Experimental TLR stimulation with the component of the bacterial wall lipopolysaccharide (LPS) promotes significant upregulation of $\mathrm{P} 2 \mathrm{X} 3$ receptor function with faster recovery from desensitization (Franceschini et al., 2013b). This treatment also facilitates release of ATP (Franceschini et al., 2012) and tumor necrosis factor alpha (TNF $\alpha$; Franceschini et al., 2013a). These data suggest that, in sensory ganglion culture, the development of a neuroinflammatory profile facilitates the release of endogenous mediators (including ATP and cytokines) to reinforce the activation of inflammatory cells and constitutively potentiates P2X3 receptors to amplify nociceptive signaling. Similar purinergic signaling likely occurs at central synapse, where block of ATP could represent a potential therapeutic target to limit microgliamediated inflammatory responses associated with chronic pain sensitization (Ulmann et al., 2008; Jakobsson, 2010). The possibility of ATP-mediated crosstalk also within ganglia has recently been proposed (Ceruti et al., 2008; Ohara et al., 2009; Belzer et al., 2010; Ceruti et al., 2011; Huang et al., 2013), supporting the intrinsic role of satellite glial cells for adaptation mechanisms during chronic pain (Hanani, 2012; Kung et al., 2013) and their role as inflammatory cells (van Velzen et al., 2009).

These observations suggest that there is a complex sequence of cellular responses that exert chemical tissue priming to create the basal conditions permissive for sensitization. In analogy with adaptive immune responses, we expect that interleukin (IL-1 $\beta$ ) priming causes amplification of antigen-presenting cells in ganglia, in particular satellite glial cells (Ben-Sasson et al., 2011).

\section{INTRACELLULAR SIGNALING INDUCES SENSITIZATION VIA P2X3 RECEPTOR UPREGULATION}

A major property of $\mathrm{P} 2 \mathrm{X} 3$ receptors is the ability to rapidly adapt their function to changes in the extracellular milieu via receptor redistribution, trafficking, and phosphorylation. Our former studies have demonstrated that $\mathrm{P} 2 \mathrm{X} 3$ receptors of trigeminal sensory neurons are tightly controlled by the fine balance between kinases and phosphatases, which regulate even the basal operational activity of these receptors (Giniatullin et al., 2008).

NGF is sufficient to directly sensitize nociceptive endings causing spontaneous pain (Bennett et al., 1998; Shu and Mendell, 2001; Rukwied et al., 2013), to sensitize P2X3 expressing nociceptors in mice (Ramer et al., 2001; D'Arco et al., 2007, 2009) and to induce acute sensitization of nociceptors in man (McKelvey et al., 2013; Silberstein, 2013). Manipulating NGF levels produces a major impact on ATP-mediated responses by altering intraneuronal signaling pathways (D'Arco et al., 2007; Giniatullin et al., 2008). Pharmacological blockade of protein kinase C (PKC) or Calcium/calmodulin-dependent protein kinase II (CamKII) 
activation prevents NGF-induced sensitization (Bonnington and McNaughton, 2003), and NGF neutralization unleashes the Sarcoma tyrosine kinase (Src) kinase blocker C-terminal Src kinase (Csk) to limit P2X3 receptor function at membrane level (D'Arco et al., 2009) and to inhibit neuronal sensitization (Liu et al., 2008). cAMP response element binding protein (CREB)-mediated gene expression in dorsal horn neurons establishes peripheral and central sensitization (Fang et al., 2002) suppressed by extracellular signal-regulated kinase (ERK) blockers, and by protein kinase A (PKA), PKC or CaMK inhibitors (Kawasaki et al., 2004). In line with these data, CGRP signaling pathways activate CREBmediated $\mathrm{P} 2 \mathrm{X} 3$ receptor expression and function (Simonetti et al., 2008).

Using a transgenic knock-in (KI) mouse exhibiting $\mathrm{Ca}_{\mathrm{V}} 2.1$ R192Q mutated voltage-gated calcium channels (P/Q-type) (Tottene et al., 2009), we previously identified multiple interactors (calcineurin, Cyclin-dependent kinase 5 (Cdk5) and CaMKII) associated to the gain of function of the mutated channel leading to larger intracellular calcium levels that modulate P2X3 receptor function in trigeminal sensory neurons. In particular, enhanced $\mathrm{P} 2 \mathrm{X} 3$ receptor-mediated responses are found in $\mathrm{KI}$ neurons that depend on constitutive activation of CaMKII and are reversed by the selective $\mathrm{Ca}_{\mathrm{V}} 2.1$ channel blocker $\omega$-Agatoxin or by pharmacological block of CaMKII (Nair et al., 2010a). CaMKII sensitivity to intracellular calcium levels, is an important switcher of different intracellular pathways (i.e., Cdk5) that influence P2X3 receptor activity and function, as demonstrated in mice expressing $\mathrm{Ca}_{\mathrm{V}} 2.1$ mutated channels (Nair et al., 2010a). CaMKII is also involved in P2X3 receptors export towards the surface membrane (Xu and Huang, 2004; Fabbretti et al., 2006; Hasegawa et al., 2009), a process that is largely dependent on ambient temperature (Pryazhnikov et al., 2011). Furthermore, the typical agonist-evoked desensitization of $\mathrm{P} 2 \mathrm{X} 3$ receptors is associated to dynamic, calcium-sensitive redistribution of such receptors to lipid raft domains (Vacca et al., 2009; Gnanasekaran et al., 2011) and internalization (Vacca et al., 2011; Chen et al., 2012). Thus, the intracellular calcium homeostasis is important to modulate $\mathrm{P} 2 \mathrm{X} 3$ receptor responses, as the calcium sensor neuronal Ca2+-sensor proteins (VILIP1) forms a signaling complex with $\mathrm{P} 2 \mathrm{X}$ receptors and regulates $\mathrm{P} 2 \mathrm{X} 3$ receptor sensitivity to ATP, and it even enhances the neuronal excitability of naive dorsal root ganglion (DRG) neurons (Chaumont et al., 2008; Liu et al., 2013).

In order to transduce ATP signals to downstream responses, we hypothesize that $\mathrm{P} 2 \mathrm{X} 3$ receptors require discrete sorting to membrane compartments where, on a short term on-demand basis, all the molecular elements necessary for the correct signal transduction are anchored. Among many, calcium/calmodulindependent serine protein kinase (CASK) is a scaffold protein of emerging importance (Hsueh, 2011), sensitive to intracellular calcium, CamKII levels (Lu et al., 2003; Hodge et al., 2006; Malik et al., 2013) and Cdk5 (Samuels et al., 2007), all elements known to strongly modulate $\mathrm{P} 2 \mathrm{X} 3$ receptors (Nair et al., 2010a,b).

CASK and P2X3 receptors are found within the same macromolecular complex: our data suggest that CASK acts like a docking point to stabilize $\mathrm{P} 2 \mathrm{X} 3$ receptors expression at

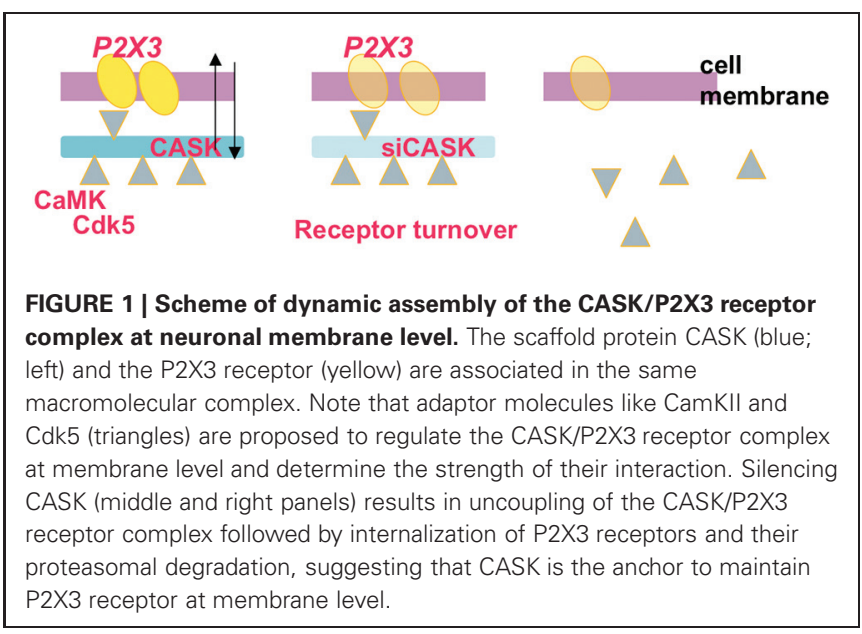

membrane level, as the CASK knockdown results in proteasomedependent receptor disassembly and reduced $\mathrm{P} 2 \mathrm{X} 3$ receptor current (Figure 1; Gnanasekaran et al., 2013). Interestingly, CASK is typically more directed to lipid rafts (Gnanasekeran and Fabbretti, unpublish data) and more strongly associated with $\mathrm{P} 2 \mathrm{X} 3$ receptors in the voltage-dependent $\mathrm{P} / \mathrm{Q}$-type calcium channel subunit alpha-1A (CACNA 1A) KI mice (Pietrobon, 2010), characterized by altered calcium channel and CamKII activity (Figure 2; Gnanasekeran et al., under revison). In the KI model, CASK/P2X3 complex is uncoupled by $\omega$-Agatoxin or the CaMKII inhibitor KN-93, reinforcing the role of intracellular calcium in the modulation of $\mathrm{P} 2 \mathrm{X} 3$ receptors in sensory neurons.

One of the peculiar findings associated with the CASK/P2X3 complex is its dynamic nature that largely depends on the receptor functional activity (Figure 3; Gnanasekaran et al., 2013). In particular, nociceptive stimulation with NGF application strengthens $\mathrm{P} 2 \mathrm{X} 3 /$ CASK co-purification, while $\mathrm{P} 2 \mathrm{X} 3$ receptor function is sufficient to dissociate the complex (Gnanasekaran et al., 2013). It is, therefore, likely that both $\mathrm{P} 2 \mathrm{X} 3$ receptor activity and CASK regulators (as CaMKII) control the CASK/P2X3 complex. In its role as scaffold protein, CASK links different adaptors and molecules (including other channels) to elicit further downstream signaling, like the stability and trafficking of receptors towards the membrane (Hsueh, 2011) and vesicle release (Spangler et al., 2013). In brain synapses, CASK has a negative role, as facilitated glutamatergic release was observed in KO CASK mice

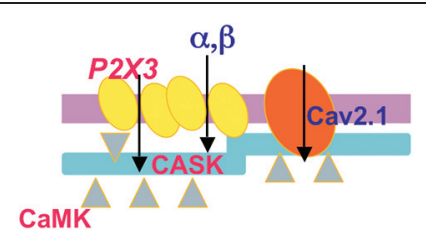

FIGURE 2 | Scheme of the CASK/P2X3 receptor complex in the R1920 mutation of the cacna1a gene. Both CASK and P2X3 receptors are more expressed in membrane lipid rafts of missense Cacna1a KI neurons, suggesting a role of CASK in creating larger P2X3 receptor clusters. Cav2.1 R192Q channel gain of function and enhanced CamKII activity produced by the increased influx of calcium are important for the formation of the CASK/P2X3 complex and receptor function. 


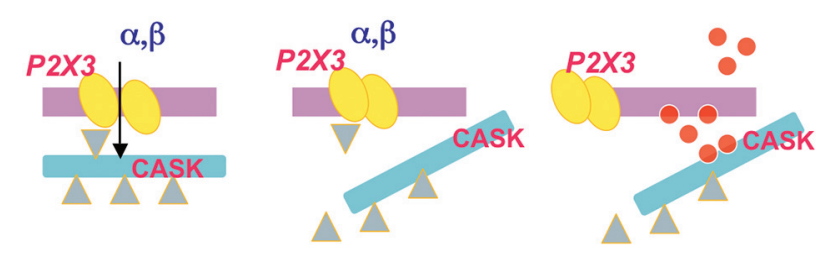

FIGURE 3 | Idealized diagram of the dynamic nature of the CASK/P2X3 complex. P2X3 receptor agonist application $(\alpha, \beta)$ induces an inward cationic current (left panel) that requires correct assembly of CASK/P2X3. When the agonist application is sustained to produce receptor desensitization, disassembly of the CASK/P2X3 complex occurs (middle). Thus, untethered CASK can be redirected to distinct downstream signaling (right panel) via multiple effectors (red dots).

(Atasoy et al., 2007), in agreement with the inhibitory effect of CASK over the P2X3 over-reactivity (Gnanasekaran et al., 2013).

Recent findings suggest that CASK, known to modulate export and trafficking of N-methyl-D-aspartate (NMDA) receptors (Jeyifous et al., 2009), induces synapse-associated protein 97 (SAP97) conformation changes to control the rate of glutamate receptor insertion into the synaptic compartment (Lin et al., 2013). Whether a similar process occurs in sensory ganglia or at central synapse, and if ATP has a role in this modulation remain a matter for future studies.

It is possible that altered CASK targeting in chronic pain states could impair communication between satellite cells and neurons via aberrant gap junction/hemichannels function (MárquezRosado et al., 2012) and with possible damage of neuro-satellite cell units. In particular, binding of CASK to neurexins and neuroligins in heterologous synapses (Fairless et al., 2008; Gokce and Südhof, 2013), indicates its potential involvement in a structural process to shape the extent and location even of neuron/nonneuronal cell communication.

Furthermore, at central level, it seems likely that presynaptic CASK/P2X3 functional interaction regulates synaptic strength in the spinal dorsal horn, reinforcing the interest for $\mathrm{P} 2 \mathrm{X} 3$ receptors as key modulators of the fiber sensitivity in chronic pain.

\section{CONCLUSIONS}

In view of their high agonist affinity, P2X3 receptors appear as major candidates to sense even small changes in extracellular ATP and transduce them into downstream neuronal responses. Further potentiation of the ATP effects is determined by intracellular calcium signaling and subsequent kinase activation that mediates $\mathrm{P} 2 \mathrm{X} 3$ receptor phosphorylation, expression and turn-over. Finally, membrane specialized domains could convey specific responses via dedicated signal transduction machinery whereby CASK could serve as a platform to orchestrate ATP signaling through sorting and redistribution of $\mathrm{P} 2 \mathrm{X} 3$ receptors. ATP receptor stimulation could determine further release of neuromodulators (Gu and MacDermott, 1997), recruitment of inflammatory cells and progression to neuronal sensitization, thus contributing to fine regulatory mechanisms and strong plasticity of sensory neurons. Understanding the spatio-temporal scale of these processes is a priority to propose molecular targets useful for clinical applications to chronic pain.

\section{ACKNOWLEDGMENTS}

This work was financially supported by Cross-border Cooperation Programme Italy-Slovenia 2007-2013, project MINA, and projects financed by Republic of Slovenia, Ministry for Economic development and technology (Kreativno jedro AHA-MOMENT) and Public Agency for Research of Republic of Slovenia (ARRS projects no. J3-5503 and J3-2376).

\section{REFERENCES}

Atasoy, D., Schoch, S., Ho, A., Nadasy, K. A., Liu, X., Zhang, W., et al. (2007). Deletion of CASK in mice is lethal and impairs synaptic function. Proc. Natl. Acad. Sci. U S A 104, 2525-2530. doi: 10.1073/pnas.0611003104

Bardoni, R., Goldstein, P. A., Lee, C. J., Gu, J. G., and MacDermott, A. B. (1997). ATP P2X receptors mediate fast synaptic transmission in the dorsal horn of the rat spinal cord. J. Neurosci. 17, 5297-5304.

Basbaum, A. I., Bautista, D. M., Scherrer, G., and Julius, D. (2009). Cellular and molecular mechanisms of pain. Cell 139, 267-284. doi: 10.1016/j.cell.2009.09. 028

Belzer, V., Shraer, N., and Hanani, M. (2010). Phenotypic changes in satellite glial cells in cultured trigeminal ganglia. Neuron Glia Biol. 6, 237-243. doi: 10. 1017/s1740925x1100007x

Bennett, D., Koltzenburg, M., Priestley, J. V., Shelton, D. L., and McMahon, S. B. (1998). Endogenous nerve growth factor regulates the sensitivity of nociceptors in the adult rat. Eur. J. Neurosci. 10, 1282-1291. doi: 10.1046/j.1460-9568.1998. 00139.x

Ben-Sasson, S. L. Z., Caucheteux, S., Crank, M., Hu-Li, J., and Paul, W. E. (2011). IL-1 acts on T cells to enhance the magnitude of in vivo immune responses. Cytokine 56, 122-125. doi: 10.1016/j.cyto.2011.07.006

Bonnington, J. K., and McNaughton, P. A. (2003). signaling pathways involved in the sensitisation of mouse nociceptive neurones by nerve growth factor. J. Physiol. 551, 433-446. doi: 10.1113/jphysiol.2003.039990

Browne, L., and North, R. A. (2013). P2X receptor intermediate activation states have altered nucleotide selectivity. J. Neurosci. 33, 14801-14808. doi: 10. 1523/jneurosci.2022-13.2013

Burnstock, G. (2008). Purinergic signaling and disorders of the central nervous system. Nat. Rev. Drug Discov. 7, 575-590. doi: 10.1038/nrd2605

Cady, R. J., Glenn, J. R., Smith, K. M., and Durham, P. L. (2011). Calcitonin gene-related peptide promotes cellular changes in trigeminal neurons and glia implicated in peripheral and central sensitization. Mol. Pain 7:94. doi: 10. 1186/1744-8069-7-94

Ceruti, S., Fumagalli, M., Villa, G., Verderio, C., and Abbracchio, M. P. (2008). Purinoceptor-mediated calcium signaling in primary neuron-glia trigeminal cultures. Cell Calcium 43, 576-590. doi: 10.1016/j.ceca.2007.10.003

Ceruti, S., Villa, G., Fumagalli, M., Colombo, L., Magni, G., Zanardelli, M., et al. (2011). Calcitonin gene-related peptide-mediated enhancement of purinergic neuron/glia communication by the algogenic factor bradykinin in mouse trigeminal ganglia from wild-type and R192Q Cav2.1 knock-in mice: implications for basic mechanisms of migraine pain. J. Neurosci. 31, 3638-3649. doi: 10. 1523/jneurosci.6440-10.2011

Chaumont, S., Compan, V., Toulme, E., Richler, E., Housley, G. D., Rassendren, F., et al. (2008). Regulation of P2X2 receptors by the neuronal calcium sensor VILIP1. Sci. Signal. 1, ra8. doi: 10.1126/scisignal.1162329

Chen, X. Q., Wang, B., Wu, C., Pan, J., Yuan, B., Su, Y. Y., et al. (2012). Endosomemediated retrograde axonal transport of $\mathrm{P} 2 \mathrm{X} 3$ receptor signals in primary sensory neurons. Cell Res. 22, 677-696. doi: 10.1038/cr.2011.197

Christianson, C. A., Dumlao, D. S., Stokes, J. A., Dennis, E. A., Svensson, C. I., Corr, M., et al. (2011). Spinal TLR4 mediates the transition to a persistent mechanical hypersensitivity after the resolution of inflammation in serum-transferred arthritis. Pain 152, 2881-2891. doi: 10.1016/j.pain.2011. 09.020

Cockayne, D. A., Dunn, P. M., Zhong, Y., Rong, W., Hamilton, S. G., Knight, G. E., et al. (2005). P2X2 knockout mice and P2X2/P2X3 double knockout mice reveal a role for the $\mathrm{P} 2 \mathrm{X} 2$ receptor subunit in mediating multiple sensory effects of ATP. J. Physiol. 567, 621-639. doi: 10.1113/jphysiol.2005.088435

Cockayne, D. A., Hamilton, S. G., Zhu, Q. M., Dunn, P. M., Zhong, Y., Novakovic, S., et al. (2000). Urinary bladder hyporeflexia and reduced painrelated behaviour in P2X3-deficient mice. Nature 407, 1011-1015. doi: 10. 1038/35039519 
Corriden, R., and Insel, P. A. (2010). Basal release of ATP: an autocrineparacrine mechanism for cell regulation. Sci. Signal. 3:re1. doi: 10.1126/scisignal. 3104rel

D’Arco, M., Giniatullin, R., Leone, V., Carloni, P., Birsa, N., Nair, A., et al. (2009). The C-terminal Src inhibitory kinase (Csk)-mediated tyrosine phosphorylation is a novel molecular mechanism to limit $\mathrm{P} 2 \mathrm{X} 3$ receptor function in mouse sensory neurons. J. Biol. Chem. 284, 21393-21401. doi: 10.1074/jbc.m109. 023051

D’Arco, M., Giniatullin, R., Simonetti, M., Fabbro, A., Nair, A., Nistri, A., et al. (2007). Neutralization of NGF induces plasticity of ATP-sensitive P2X3 receptors of nociceptive trigeminal ganglion neurons. J. Neurosci. 27, 8190 8201. doi: 10.1523/JNEUROSCI.0713-07.2007

Ellis, A., and Bennett, D. L. (2013). Neuroinflammation and the generation of neuropathic pain. Br. J. Anaesth. 111, 26-37. doi: 10.1093/bja/aet128

Fabbretti, E., D’Arco, M., Fabbro, A., Simonetti, M., Nistri, A., and Giniatullin, R. (2006). Delayed sensitization of ATP P2X3 receptors of trigeminal sensory neurons by calcitonin Gene-related peptide. J. Neurosci. 26, 6163-6171. doi: 10. 1523/jneurosci.0647-06.2006

Fabbretti, E., and Nistri, A. (2012). Structure and function of pain-transducing P2X3 receptors. CNS Neurol. Disord. Drug Targets 11, 687-698.

Fairless, R., Masius, H., Rohlmann, A., Heupel, K., Ahmad, M., and Reissner, C. (2008). Polarized targeting of neurexins to synapses is regulated by their Cterminal sequences. J. Neurosci. 28, 12969-12981. doi: 10.1523/jneurosci.529407.2008

Fang, L., Wu, J., Lin, Q., and Willis, W. D. (2002). Calcium-calmodulin-dependent protein kinase II contributes to spinal cord central sensitization. J. Neurosci. 22, 4196-4204.

Ford, A. P. (2012). In pursuit of P2X3 antagonists: novel therapeutics for chronic pain and afferent sensitization. Purinergic Signal. 8, 3-26. doi: 10.1007/s11302011-9271-6

Franceschini, A., Hullugundi, S. K., van den Maagdenberg, A. M. J. M., Nistri, A., and Fabbretti, E. (2013b). Effects of LPS on P2X3 receptors of trigeminal sensory neurons and macrophages from mice expressing the R192Q Cacnala gene mutation of familial hemiplegic migraine-1. Purinergic Signal. 9, 7-13. doi: 10.1007/s11302-012-9328-1

Franceschini, A., Nair, A., Bele, T., Hullugundi, S. K., van den Maagdenberg, A. M. J. M., Nistri, A., et al. (2012). Functional crosstalk in culture between macrophages and trigeminal sensory neurons of a mouse genetic model of migraine. BMC Neurosci. 13:143. doi: 10.1186/1471-2202-13-143

Franceschini, A., Vilotti, S., Ferrari, M. D., van den Maagdenberg, A. M. J. M., Nistri, A., and Fabbretti, E. (2013a). TNFalpha levels and macrophages expression reflect an inflammatory potential of trigeminal ganglia in a mouse model of familial hemiplegic migraine. PLoS One 8:e52394. doi: 10.1371/journal.pone. 0052394

Giniatullin, R., Nistri, A., and Fabbretti, E. (2008). Molecular modulation of ATPgated P2X3 receptors involved in pain. Mol. Neurobiol. 37, 83-90. doi: 10. 1007/s12035-008-8020-5

Gnanasekaran, A., Sundukova, M., Hullugundi, S., Birsa, N., Bianchini, G., Hsueh, Y. P., et al. (2013). CASK is a new intracellular modulator of $\mathrm{P} 2 \mathrm{X} 3$ receptors. $J$ Neurochem. 126, 102-112. doi: 10.1111/jnc.12272

Gnanasekaran, A., Sundukova, M., van den Maagdenberg, A., Fabbretti, E., and Nistri, A. (2011). Lipid rafts control P2X3 receptor distribution and function in trigeminal sensory neurons of a transgenic migraine mouse model. Mol. Pain 7:77. doi: 10.1186/1744-8069-7-77

Gokce, O., and Südhof, T. C. (2013). Membrane-tethered monomeric neurexin LNS-domain triggers synapse formation. J. Neurosci. 33, 14617-14628. doi: 10. 1523/jneurosci.1232-13.2013

Gu, J. G., and MacDermott, A. B. (1997). Activation of ATP P2X receptors elicits glutamate release from sensory neuron synapses. Nature 389, 749-753. doi: 10 . $1038 / 39639$

Hamilton, S. G., and McMahon, S. B. (2000). ATP as a peripheral mediator of pain. J. Auton. Nerv. Syst. 81, 187-194. doi: 10.1016/s0165-1838(00)00137-5

Hanani, M. (2012). Intercellular communication in sensory ganglia by purinergic receptors and gap junctions: implications for chronic pain. Brain Res. 1487, 183 191. doi: 10.1016/j.brainres.2012.03.070

Hasegawa, S., Kohro, Y., Tsuda, M., and Inoue, K. (2009). Activation of cytosolic phospholipase A2 in dorsal root ganglion neurons by $\mathrm{Ca}^{2+} /$ calmodulindependent protein kinase II after peripheral nerve injury. Mol. Pain 5:22. doi: 10. $1186 / 1744-8069-5-22$
Hilliges, M., Weidner, C., Schmelz, M., Schmidt, R., Ørstavik, K., Torebjörk, E. et al. (2002). ATP responses in human C nociceptors. Pain 98, 59-68. doi: 10. 1016/s0304-3959(01)00469-9

Hodge, J. J., Mullasseril, P., and Griffith, L. C. (2006). Activity-dependent gating of CaMKII autonomous activity by Drosophila CASK. Neuron 51, 327-337. doi: 10.1016/j.neuron.2006.06.020

Hsueh, Y. P. (2011). A versatile player. J. Mol. Biol. 412, 1-2. doi: 10.1016/j.jmb. 2011.07.040

Huang, L. Y., Gu, Y., and Chen, Y. (2013). Communication between neuronal somata and satellite glial cells in sensory ganglia. Glia 61, 1571-1581. doi: 10. 1002/glia.22541

Inoue, K., and Tsuda, M. (2012). P2X4 receptors of microglia in neuropathic pain. CNS Neurol. Disord. Drug Targets 11, 699-704. doi: 10. 2174/187152712803581065

Jakobsson, P. J. (2010). Pain: how macrophages mediate inflammatory pain via ATP signaling. Nat. Rev. Rheumatol. 6, 679-681. doi: 10.1038/nrrheum.2010.175

Jarvis, M. F., Burgard, E. C., McGaraughty, S., Honore, P., Lynch, K., Brennan, T. J., et al. (2002). A-317491, a novel potent and selective non-nucleotide antagonist of $\mathrm{P} 2 \mathrm{X} 3$ and $\mathrm{P} 2 \mathrm{X} 2 / 3$ receptors, reduces chronic inflammatory and neuropathic pain in the rat. Proc. Natl. Acad. Sci. U S A 99, 17179-17184. doi: 10.1073/pnas 252537299

Jeyifous, O., Waites, C. L., Specht, C. G., Fujisawa, S., Schubert, M., Lin, E. I., et al. (2009). SAP97 and CASK mediate sorting of NMDA receptors through a previously unknown secretory pathway. Nat. Neurosci. 12, 1011-1019. doi: 10. 1038/nn.2362

Kawasaki, Y., Kohno, T., Zhuang, Z. Y., Brenner, G. J., Wang, H., Van Der Meer, C., et al. (2004). Ionotropic and metabotropic receptors, protein kinase A protein kinase $\mathrm{C}$, and Src contribute to $\mathrm{C}$-fiber-induced ERK activation and cAMP response element-binding protein phosphorylation in dorsal horn neurons, leading to central sensitization. J. Neurosci. 24, 8310-8321. doi: 10 1523/jneurosci.2396-04.2004

Kuner, R. (2010). Central mechanisms of pathological pain. Nat. Med. 16, 1258 1266. doi: $10.1038 / \mathrm{nm} .2231$

Kung, L. H., Gong, K., Adedoyin, M., Ng, J., Bhargava, A., Ohara, P. T., et al. (2013). Evidence for glutamate as a neuroglial transmitter within sensory ganglia. PLoS One 8:e68312. doi: 10.1371/journal.pone.0068312

Lin, E. I., Jeyifous, O., and Green, W. N. (2013). CASK regulates SAP97 conformation and its interactions with AMPA and NMDA receptors. J. Neurosci. 33, 12067-12076. doi: 10.1523/jneurosci.0816-13.2013

Liu, X. J., Gingrich, J. R., Vargas-Caballero, M., Dong, Y. N., Sengar, A., Beggs, S., et al. (2008). Treatment of inflammatory and neuropathic pain by uncoupling Src from the NMDA receptor complex. Nat. Med. 14, 1325-1332. doi: 10. 1038/nm.1883

Liu, M., Yang, H., Fang, D., Yang, J. J., Cai, J., Wan, Y., et al. (2013). Upregulation of $\mathrm{P} 2 \mathrm{X} 3$ receptors by neuronal calcium sensor protein VILIP-1 in dorsal root ganglions contributes to the bone cancer pain in rats. Pain 154, 1551-1568. doi: 10.1016/j.pain.2013.04.022

Lu, C. S., Hodge, J. J., Mehren, J., Sun, X. X., and Griffith, L. C. (2003). Regulation of the $\mathrm{Ca}^{2+} / \mathrm{CaM}$-responsive pool of CaMKII by scaffold-dependent autophosphorylation. Neuron 40, 1185-1197. doi: 10.1016/s0896-6273(03)00786-4

Malik, B. R., Gillespie, J. M., and Hodge, J. J. (2013). CASK and CaMKII function in the mushroom body $\alpha^{\prime} / \beta^{\prime}$ neurons during Drosophila memory formation. Front. Neural. Circuits 7:94. doi: 10.3389/fncir.2013.00052

Márquez-Rosado, L., Singh, D., Rincón-Arano, H., Solan, J. L., and Lampe, P. D. (2012). CASK (LIN2) interacts with $\mathrm{Cx} 43$ in wounded skin and their coexpression affects cell migration. J. Cell Sci. 125(Pt 3), 695-702. doi: 10.1242/jcs. 084400

McCleskey, E. W., and Gold, M. S. (1999). Ion channels of nociception. Annu. Rev Physiol. 61, 835-856. doi: 10.1007/978-3-540-72739-2_13

McKelvey, L., Shorten, G. D., and O'Keeffe, G. W. (2013). Nerve growth factormediated regulation of pain signaling and proposed new intervention strategies in clinical pain management. J. Neurochem. 124, 276-289. doi: 10. $1111 /$ jnc. 12093

Moeller-Bertram, T., Schilling, J. M., Bačkonja, M. M., and Nemenov, M. I (2013). Sensory small fiber function differentially assessed with diode laser (DL) quantitative sensory testing (QST) in painful neuropathy (PN). Pain Med. 14, 417-421. doi: 10.1111/pme.12049

Nair, A., Simonetti, M., Birsa, N., Ferrari, M., van den Maagdenberg, A., Giniatullin, R., et al. (2010a). Familial hemiplegic migraine Cav21 channel 
mutation R192Q confers higher P2X3 receptor activity to mouse trigeminal ganglion neurons in vitro and in vivo. Mol. Pain 6:48. doi: 10.1186/1744-80696-48

Nair, A., Simonetti, M., Fabbretti, E., and Nistri, A. (2010b). The Cdk5 kinase downregulates ATP-gated ionotropic $\mathrm{P} 2 \mathrm{X} 3$ receptor function via serine phosphorylation. Cell Molec. Neurosci. 30, 505-509. doi: 10.1007/s10571-0099483-2

North, R. A., and Jarvis, M. F. (2013). P2X receptors as drug targets. Mol. Pharmacol. 83, 759-769. doi: 10.1124/mol.112.083758

Novak, I. (2011). Purinergic signaling in epithelial ion transport: regulation of secretion and absorption. Acta Physiol. 202, 501-522. doi: 10.1111/j.1748-1716. 2010.02225.x

Ohara, P. T., Vit, J. P., Bhargava, A., Romero, M., Sundberg, C., Charles, A. C., et al. (2009). Gliopathic pain: when satellite glial cells go bad. Neuroscientist 15, 450463. doi: $10.1177 / 1073858409336094$

Pietrobon, D. (2010). Insights into migraine mechanisms and Cav2.1 calcium channel function from mouse models of familial hemiplegic migraine. J. Physiol. 588, 1871-1878. doi: 10.1113/jphysiol.2010.188003

Pryazhnikov, E., Fayuk, D., Niittykoski, M., Giniatullin, R., and Khiroug, L. (2011). Unusually strong temperature dependence of $\mathrm{P} 2 \mathrm{X} 3$ receptor traffic to the plasma membrane. Front. Cell Neurosci. 5:27. doi: 10.3389/fncel.2011.00027

Ramer, M. S., Bradbury, E. J., and McMahon, S. B. (2001). Nerve growth factor induces P2X3 expression in sensory neurons. J. Neurochem. 77, 864-875. doi: 10. 1046/j.1471-4159.2001.00288.x

Rukwied, R., Weinkauf, B., Main, M., Obreja, O., and Schmelz, M. (2013). Inflammation meets sensitization - an explanation for spontaneous nociceptor activity? Pain doi: 10.1016/j.pain.2013.07.054. [Epub ahead of print].

Samuels, B. A., Hsueh, Y. P., Shu, T., Liang, H., Tseng, H. C., Hong, C. J., et al. (2007). Cdk5 promotes synaptogenesis by regulating the subcellular distribution of the MAGUK family member CASK. Neuron 56, 823-837. doi: 10.1016/j. neuron.2007.09.035

Serrano, A., Mo, G., Grant, R., Paré, M., O’Donnell, D., Yu, X. H., et al. (2012). Differential expression and pharmacology of native $\mathrm{P} 2 \mathrm{X}$ receptors in rat and primate sensory neurons. J. Neurosci. 32, 11890-11896. doi: 10.1523/jneurosci. 0698-12.2012

Shields, S. D., Cavanaugh, D. J., Lee, H., Anderson, D. J., and Basbaum, A. I. (2010). Pain behavior in the formalin test persists after ablation of the great majority of C-fiber nociceptors. Pain 151, 422-429. doi: 10.1016/j.pain.2010.08.001

Shu, X., and Mendell, L. M. (2001). Acute sensitization by NGF of the response of small-diameter sensory neurons to capsaicin. J. Neurophysiol. 86, 2931-2938.

Silberstein, S. D. (2013). Emerging target-based paradigms to prevent and treat migraine. Clin. Pharmacol. Ther. 93, 78-85. doi: 10.1038/clpt.2012.198

Simonetti, M., Giniatullin, R., and Fabbretti, E. (2008). Mechanism mediating the enhanced transcription of $\mathrm{P} 2 \mathrm{X} 3$ receptor gene by calcitonin gene related peptide in trigeminal sensory neurons. J. Biol. Chem. 283, 18743-18752. doi: 10. 1074/jbc.m800296200

Sokolova, E., Skorinkin, A., Moiseev, I., Agrachev, A., Nistri, A., and Giniatullin, R. (2006). Experimental and modeling studies of desensitization of P2X3 receptors. Mol. Pharmacol. 70, 373-382. doi: 10.1124/mol.106.023564

Souslova, V., Cesare, P., Ding, Y., Akopian, A. N., Stanfa, L., Suzuki, R., et al. (2000). Warm-coding deficits and aberrant inflammatory pain in mice lacking P2X3 receptors. Nature 407, 1015-1017. doi: 10.1038/35039526

Spangler, S. A., Schmitz, S. K., Kevenaar, J. T., de Graaff, E., de Wit, H., Demmers, J., et al. (2013). Liprin- $\alpha 2$ promotes the presynaptic recruitment and turnover of RIM1/CASK to facilitate synaptic transmission. J. Cell Biol. 201, 915-928. doi: $10.1083 /$ jcb.201301011

Stokes, J. A., Corr, M., and Yaksh, T. L. (2013). Spinal toll-like receptor signaling and nociceptive processing: regulatory balance between TIRAP and TRIF cascades mediated by TNF and IFN $\beta$. Pain 154, 733-742. doi: 10.1016/j.pain.2013.01.012

Sundukova, M., Vilotti, S., Abbate, R., Fabbretti, E., and Nistri, A. (2012). Functional differences between ATP-gated human and rat $\mathrm{P} 2 \mathrm{X} 3$ receptors are caused by critical residues of C-terminal domain. J. Neurochem. 122, 557-567. doi: 10. 1111/j.1471-4159.2012.07810.x.
Tottene, A., Conti, R., Fabbro, A., Vecchia, D., Shapovalova, M., Santello, M., et al. (2009). Enhanced excitatory transmission at cortical synapses as the basis for facilitated spreading depression in Cav2.1 knockin migraine mice. Neuron 61, 762-773. doi: 10.1016/j.neuron.2009.01.027

Toulme, E., Tsuda, M., Khakh, B. S., and Inoue, K. (2010). "On the role of ATP-Gated P2X receptors in acute, inflammatory and neuropathic pain," in Translational Pain Research: From Mouse to Man, eds L. Kruger and A. R. Light (Boca Raton, FL: CRC Press).

Tzabazis, A. Z., Klukinov, M., Crottaz-Herbette, S., Nemenov, M. I., Angst, M. S., and Yeomans, D. C. (2011). Selective nociceptor activation in volunteers by infrared diode laser. Mol. Pain 7:18. doi: 10.1186/1744-8069-7-18

Ueda, H. (2008). Peripheral mechanisms of neuropathic pain - involvement of lysophosphatidic acid receptor-mediated demyelination. Mol. Pain 4:11. doi: 10. 1186/1744-8069-4-11

Ulmann, L., Hatcher, J. P., Hughes, J. P., Chaumont, S., Green, P. J., Conquet, F., et al. (2008). Up-regulation of P2X4 receptors in spinal microglia after peripheral nerve injury mediates BDNF release and neuropathic pain. J. Neurosci. 28, 11263-11268. doi: 10.1523/jneurosci.2308-08.2008

Vacca, F., D’Ambrosi, N., Nestola, V., Amadio, S., Giustizieri, M., Cucchiaroni, M. L., et al. (2011). N-Glycans mutations rule oligomeric assembly and functional expression of $\mathrm{P} 2 \mathrm{X} 3$ receptor for extracellular ATP. Glycobiology 21, 634643. doi: 10.1093/glycob/cwq211

Vacca, F., Giustizieri, M., Ciotti, M. T., Mercuri, N. B., and Volonté, C. (2009). Rapid constitutive and ligand-activated endocytic trafficking of $\mathrm{P} 2 \mathrm{X}$ receptor. J. Neurochem. 109, 1031-1041. doi: 10.1111/j.1471-4159.2009.06029.x

van Velzen, M., Laman, J. D., Kleinjan, A., Poot, A., Osterhaus, A. D., and Verjans, G. M. (2009). Neuron-interacting satellite glial cells in human trigeminal ganglia have an APC phenotype. J. Immunol. 183, 2456-2461. doi: 10.4049/jimmunol. 0900890

Villa, G., Ceruti, S., Zanardelli, M., Magni, G., Jasmin, L., Ohara, P. T., et al. (2010). Temporomandibular joint inflammation activates glial and immune cells in both the trigeminal ganglia and in the spinal trigeminal nucleus. Mol. Pain 6:89. doi: 10.1186/1744-8069-6-89

Vulchanova, L., Riedl, M. S., Shuster, S. J., Stone, L. S., Hargreaves, K. M., Buell, G., et al. (1998). P2X3 is expressed by DRG neurons that terminate in inner lamina II. Eur. J. Neurosci. 10, 3470-3478. doi: 10.1046/j.1460-9568.1998.00355.x

$\mathrm{Xu}, \mathrm{G}$. Y., and Huang, L. Y. (2004). $\mathrm{Ca}^{2+} /$ calmodulin-dependent protein kinase II potentiates ATP responses by promoting trafficking of P2X receptors. Proc. Natl. Acad. Sci. U S A 101, 11868-11873. doi: 10.1073/pnas.0401490101

Zhang, J., Cavanaugh, D. J., Nemenov, M. I., and Basbaum, A. I. (2013). The modality-specific contribution of peptidergic and non-peptidergic nociceptors is manifest at the level of dorsal horn nociresponsive neurons. J. Physiol. 591, 1097-1110. doi: 10.1113/jphysiol.2012.242115

Zhong, Y., Dunn, P. M., Bardini, M., Ford, A. P., Cockayne, D. A., and Burnstock, G. (2001). Changes in P2X receptor responses of sensory neurons from P2X3deficient mice. Eur. J. Neurosci. 14, 1784-1792. doi: 10.1046/j.0953-816x.2001. 01805.x

Conflict of Interest Statement: The authors declare that the research was conducted in the absence of any commercial or financial relationships that could be construed as a potential conflict of interest.

Received: 08 October 2013; paper pending published: 18 October 2013; accepted: 08 November 2013; published online: 04 December 2013.

Citation: Fabbretti E (2013) ATP P2X3 receptors and neuronal sensitization. Front. Cell. Neurosci. 7:236. doi: 10.3389/fncel.2013.00236

This article was submitted to the journal Frontiers in Cellular Neuroscience.

Copyright (c) 2013 Fabbretti. This is an open-access article distributed under the terms of the Creative Commons Attribution License (CC BY). The use, distribution or reproduction in other forums is permitted, provided the original author(s) or licensor are credited and that the original publication in this journal is cited, in accordance with accepted academic practice. No use, distribution or reproduction is permitted which does not comply with these terms. 